\title{
High resolution mapping of interstitial long arm deletions of chromosome 16: relationship to phenotype
}

\author{
D F Callen, H Eyre, S Lane, Y Shen, I Hansmann, N Spinner, E Zackai, \\ D McDonald-McGinn, S Schuffenhauer, J Wauters, M-N Van Thienen, B Van Roy, \\ G R Sutherland, E A Haan
}

ated with del(5)(p15.3). As for partial and full trisomies, it is likely that one or a few genes are involved in producing the abnormal phenotype.

Aneuploidy for the entire chromosome 16 is lethal. Trisomy 16 is found in approximately $5 \%$ of spontaneous abortuses. This trisomy has a lethal effect early in pregnancy with the average gestational age being approximately 10 weeks, and a blighted ovum most frequently observed, although occasional embryos up to $10 \mathrm{~mm}$ long have been described. ${ }^{2}$ Monosomy for this chromosome has not been reported in studies of abortion material, although karyotyping of sperm shows that this aneuploidy probably occurs. $^{3}$

To our knowledge, there have been no confirmed partial monosomies for the very distal segment of the long arm of chromosome 16. A patient reported as a $\operatorname{del}(16)(\mathrm{q} 22)^{4}$ was subsequently shown to be a balanced $t(5 ; 16)$ translocation. ${ }^{5}$ A malformed newborn with a karyotype $46, \mathrm{XX}, \operatorname{del}(16)(\mathrm{q} 21)$ was reported in 1977.6 However, the quality of chromosome banding available at that time was probably not sufficient to establish the exact nature of this deletion. Monosomy for this region of the chromosome might be expected to be generated from the meiotic segregation of translocations with breakpoints in this region but no cases have been reported to our knowledge. In contrast, a number of patients with interstitial long arm deletions of chromosome 16 have been reported. Some of these patients have similar patterns of malformations and this has resulted in the concept of a deletion syndrome involving the long arm of chromosome 16 . However, the identification of a critical region for this deletion syndrome has been ambiguous, with both $16 \mathrm{q} 12-13^{78}$ and $16 \mathrm{q} 22.1^{9}$ being suggested as critical.

In this study, a high resolution cytogenetic based physical map of chromosome 16 has been used to enable detailed localisation of the long arm breakpoints of seven chromosome $16 \mathrm{q}$ interstitial deletions and two ring chromosomes. specific region of the chromosome, with features likely to be the result of imbalance of one or few genes. ${ }^{1}$

Autosomal chromosome monosomies are lethal. However, partial monosomies, often originating as meiotic segregants from parental balanced translocations, can be viable and be associated with a specific recognisable pattern of malformations. Common examples are the Wolf-Hirschhorn syndrome associated with $\operatorname{del}(4)(\mathrm{p} 16.3)$ and cri du chat syndrome associ-

\section{Materials and methods}

CELL LINES

The origin of the seven interstitial deletion and two ring chromosomes 16 is given in table 1. Four of the cell lines were fused with the mouse cell line A9 and mouse/human somatic cell hybrids isolated containing the deleted

\footnotetext{
Correspondence to Dr Callen.

Received 11 January 1993 Revised version accepted 27 May 1993.

Department of

Women's and

Australia.
} 
Table 1 Origin of cell lines.

\begin{tabular}{lll}
\hline Identifier & Reference/origin & Hybrid cell line* \\
\hline Interstitial deletions of $16 \mathrm{q}$ & 10 & CY138 \\
ID1 & 11 & - \\
ID2 & 12 & CY130 \\
ID3 & This report & CY127 \\
ID4 & 13 & CY125 \\
ID5 & 14 & - \\
ID6† & This report & - \\
ID7 & & \\
Ring chromosome 16 & 15 & - \\
R1 & 16 & - \\
R2 & 16 & \\
\hline
\end{tabular}

* Construction and characterisation of mouse/human hybrid lines reported in Callen et al. ${ }^{17}$

† Available from Human Genetic Mutant Cell Repository (Camden) as GM9101.

chromosome 16 in the absence of the normal $16 .{ }^{17}$

MOLECULAR MAPPING OF BREAKPOINTS

The long arm breakpoints of the interstitial deletions and of the ring chromosomes were mapped in relation to the high resolution cytogenetic based physical map of chromosome 16 by three different procedures. For four deletions the availability of somatic cell hybrids allowed mapping of the deletions by Southern blot or PCR analysis of the hybrid cell DNA. ${ }^{17}$ Breakpoints of the remaining cell lines were localised by mapping DNA markers by fluorescence in situ hybridisation (FISH) to metaphase spreads as previously described. ${ }^{18} \mathrm{~A}$ DNA marker was considered to be outside of the deletion when signal was seen on both the deleted and normal chromosomes. A DNA marker was scored as being within the deletion if there was signal observed on only one chro-

Table 2 Mapping of breakpoints of deletions on the long arm of chromosome 16.

\begin{tabular}{llllll}
\hline & \multicolumn{5}{c}{ Deletion } \\
\cline { 2 - 6 } DNA marker & ID2 & ID6 & ID7 & R1 & R2
\end{tabular}

D16S261 (MFD24)*

D16S304 (16AC1.14)*

D16S308 (16AC1.18)*

D16S390 (c10F5)

D16S187 (16-103)

CETP

D16S65 (CRI-0377)

D16S320 (16AC8.52)

D16S378 (c30E12)

D16S164 (16-15)

D16S163 (16-10)

D16S174 (16-53)

D16S4 (ACH207)

D16S397 (MFD98)*

D16S398 (MFD168)*

D16S124 (1.99)

D16S160 (CJ52.196)

UVO

D16S47 (CRI-095)

D16S47 (CRI-095)
D16S153 (CJ52.10)

(c80H3)

D16S342 (c312C6)

D16S342 (c312C6)

D16S395 (c33G11)

D16S348 (c301B4)

D16S50 (CRI-0119)

D16S377 (c306E12)

D16S344 (c16F1)

D16S157 (CJ52.96)

D16S41 (CRI-043)

APRT

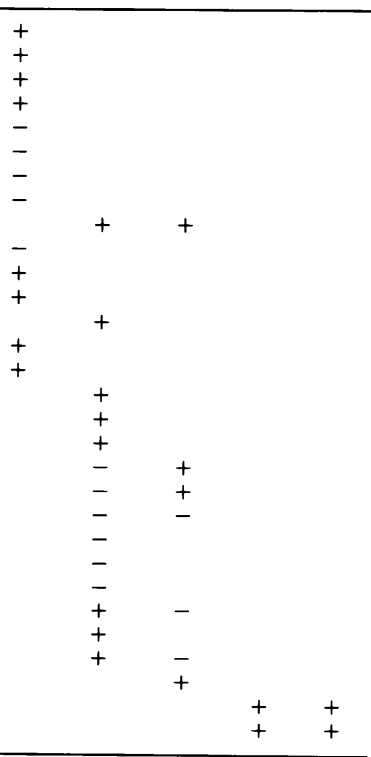

The breakpoints of ID1 and ID3-ID5 were mapped by Southern blot or PCR analysis of mouse/human somatic cell hybrids containing the deleted chromosome. ${ }^{17}$ The presence $(+)$ or absence ( - ) of a DNA marker on the chromosome 16 with a deletion was determined by FISH except in cases indicated by an asterisk where this was determined by inheritance of polymorphic (AC)n microsatellite markers. The order of DNA markers is from centromere to qter. mosome 16 in at least 10 metaphases. DNA markers were all previously mapped to the high resolution cytogenetic physical map of chromosome $16 .{ }^{17}$

The third method of mapping the extent of a deletion was by typing DNA from the proband and parents with polymorphic microsatellite (AC)n repeats. When the proband showed loss of a parental allele this indicated that the locus was contained within the deletion.

\section{CLINICAL DETAILS}

The clinical details of some of the patients have been previously reported (table 1).

Patient ID4. Delivery of this girl was at 34 weeks' gestation by caesarian section performed because of polyhydramnios and fetal distress. Birth weight was $1950 \mathrm{~g}$ (10th to 50th centile), length $45 \mathrm{~cm}$ (50th centile), and head circumference $30 \mathrm{~cm}$ (10th centile). The dysmorphic features are summarised in table 3 and include brachycephaly, cleft palate, pulmonary atresia with hypoplastic right ventricle and tricuspid valve, limited extension of finger joints, especially the distal interphalangeal joints, and proximally placed thumbs. Subsequent development was poor with failure to thrive and death at 74 days. There was no necropsy.

Patient ID6. Delivery of this girl was at term by caesarian section because of fetal decelerations. Her birth weight was $2890 \mathrm{~g}$. She was intubated in the delivery room with meconium below her vocal chords but she did not develop respiratory distress and was discharged at 5 days in good health. At 6 months decreased growth was noted and at 12 months she was referred for evaluation of developmental delay. At this time physical evaluation

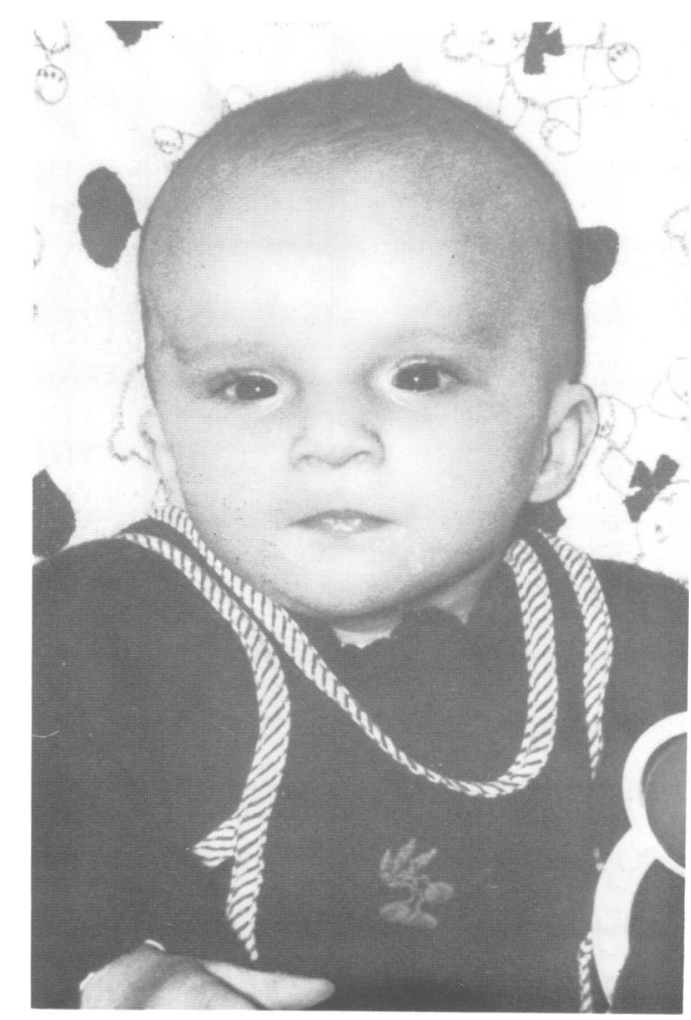

Figure 1 Photograph of patient ID7. 
showed head circumference and height at the 25 th centile for age and weight at the 3rd centile for age. She had a flat occiput and right epicanthic fold but otherwise was not dysmorphic. Re-examination at $7 \frac{1}{2}$ years showed a short, microcephalic girl with minor dysmorphism consisting of recessed hairline, slightly prominent broad forehead, supernumerary nipple (present in her normal mother), short and broad big toes, and small nails on the fifth toes. She was retarded, not toilet trained, and had general learning difficulties.

Patient ID7. This female was delivered spontaneously at 37 weeks' gestation. Birth weight was $3170 \mathrm{~g}$ (50th to 75 th centile), length $48 \mathrm{~cm}$ ( 50 th centile), and head circumference $34 \mathrm{~cm}$ ( 75 th centile). During the first few months there was normal feeding and development. At 8 weeks, clinical examination showed trembling, hypertonia, narrow palpebral fissures with antimongoloid slant, broad nasal root, flat forehead, an extremely large anterior fontanelle, long philtrum, high arched palate, and evidence of micrognathia. The two lower incisors were present at birth (both lost spontaneously at 4 weeks), the ears were low set and dysmorphic, there were flexion defects of the middle fingers, and widely spaced nipples. A photograph of the patient is presented in fig 1 .

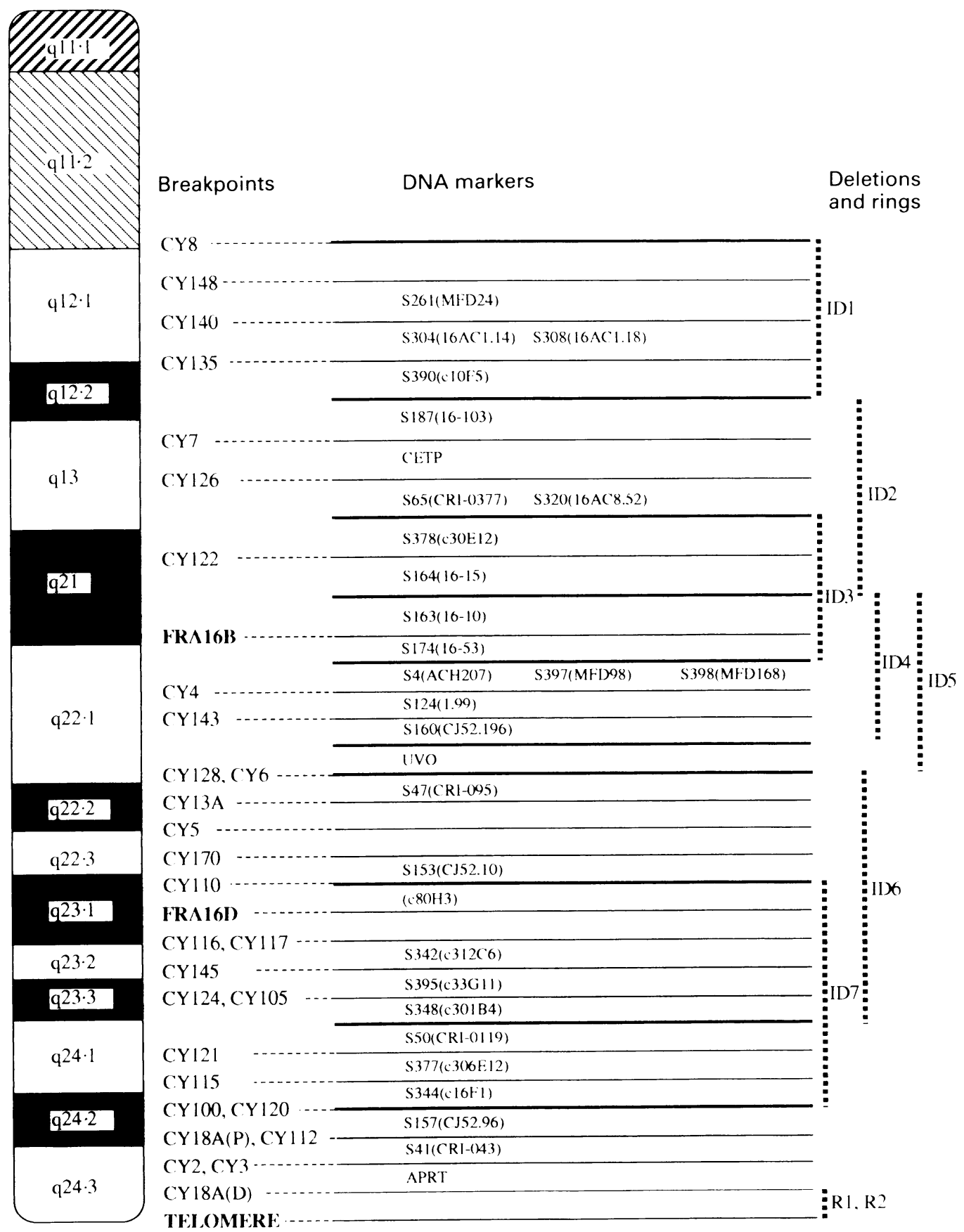

Figure 2 Ideogram of the long arm of chromosome 16 showing location of deletions. The hybrid breakpoints are designated by the prefix ' $C Y$ '. The extent of deletions is indicated by the dotted lines on the right of the ideogram. The two fragile sites, FRA16B and FRA16D, provide physical links of the panel to the chromosome at the interface of bands $16 \mathrm{~g} 21$ and $q 22.1$ and at band 16923.1 respectively. The breakpoints between CY8 and FRA16B, FRA16B of bands $16 q 21$ and $q 22.1$ and at band $16 q 23.1$ respectively. The breakpoints between $C Y 8$ and $F R A$ to breakpoints of deletions ID 1, ID3, ID4, and ID5 has been determined by analysis of the corresponding mouse human somatic cell hybrids CY138, CY130, CY127, and CY125 respectively. These data have been previously published.' 


\section{Results}

The results of mapping DNA markers to the interstitial deletions of $16 \mathrm{q}$ and the two ring chromosomes 16 are given in table 2 and presented diagrammatically in fig 2 . In two instances (ID1, ID2 and ID5, ID6) the breakpoints of the deletions mapped to the same region. Mapping of additional DNA markers would be required to resolve whether within these regions there is overlap or separation of the breakpoints. The two ring chromosomes retained APRT and therefore must be broken distal to this gene. Overall, deletions of the long arm of chromosome 16 are associated with a viable phenotype and these deletions can include regions of the entire long arm except the distal tip from q24.2 to q24.3. There is the possibility of a small region of non-overlap between ID1 and ID2, and between ID5 and ID6.

A summary of the clinical details of these patients is given in table 3. The deletion ID3 was associated with a normal phenotype. The girl with the deletion ID6 was developmentally delayed but had few dysmorphic features. There was considerable overlap present in the pattern of abnormalities seen in the other patients even though different regions of chromosome 16 were involved. These abnormalities were often relatively non-specific, and can be attributed to generalised disruption of development. More specific abnormalities are the association of ID1 with sensorineural deafness

Table 3 Summary of clinical features of patients with interstitial deletions*.

\begin{tabular}{|c|c|c|c|c|c|c|}
\hline & ID1 & ID2 & ID4 & ID5 & ID6 & ID7 \\
\hline Sex & $\mathbf{M}$ & $\mathbf{M}$ & $\mathbf{F}$ & $\mathbf{F}$ & $\mathbf{F}$ & $\mathrm{F}$ \\
\hline Death (mth) & - & - & $2 \cdot 5$ & 19 & - & - \\
\hline $\begin{array}{l}\text { Growth } \\
\text { Small for dates } \\
\text { Postnatal growth }<3 \text { rd centile } \\
\text { Microcephaly } \\
\text { Failure to thrive }\end{array}$ & $\begin{array}{l}- \\
+ \\
+ \\
+\end{array}$ & $\begin{array}{l}- \\
+ \\
+ \\
+\end{array}$ & $\begin{array}{l}- \\
+ \\
+/- \\
+\end{array}$ & $\begin{array}{l}+ \\
+ \\
+ \\
+\end{array}$ & $\begin{array}{l}- \\
+ \\
+ \\
+\end{array}$ & $\begin{array}{l}- \\
- \\
- \\
+\end{array}$ \\
\hline $\begin{array}{l}\text { CNS and development } \\
\text { Psychomotor retardation } \\
\text { Hypotonia } \\
\text { Feeble suck } \\
\text { Hydrocephalus } \\
\text { Deafness (sensorineural) }\end{array}$ & $\begin{array}{l}+ \\
+ \\
+ \\
+ \\
+\end{array}$ & $\begin{array}{l}+ \\
+ \\
+ \\
-\end{array}$ & $\begin{array}{l}+ \\
+ \\
+ \\
-\end{array}$ & $\begin{array}{l}+ \\
+ \\
+ \\
-\end{array}$ & $\begin{array}{l}+ \\
+ \\
- \\
-\end{array}$ & $\begin{array}{l}+ \\
- \\
- \\
-\end{array}$ \\
\hline $\begin{array}{l}\text { Craniofacial } \\
\text { Large anterior fontanelle } \\
\text { High forehead } \\
\text { Diastasis of cranial sutures } \\
\text { Prominent metopic sutures } \\
\text { Broad flat nasal bridge } \\
\text { Hypertelorism } \\
\text { Low set, dysmorphic ears } \\
\text { Short palpebral fissures } \\
\text { Upward slanting palpebral fissures } \\
\text { Micrognathia } \\
\text { High arched/cleft palate } \\
\text { Cervical vertebral anomalies } \\
\text { High arched eyebrows }\end{array}$ & $\begin{array}{l}? \\
+ \\
? \\
+ \\
- \\
+ \\
+ \\
+ \\
+ \\
+ \\
+ \\
+ \\
+\end{array}$ & $\begin{array}{l}+ \\
+ \\
- \\
+ \\
+ \\
+ \\
+ \\
- \\
- \\
+ \\
- \\
-\end{array}$ & $\begin{array}{c}+ \\
+1- \\
+ \\
- \\
+ \\
- \\
+ \\
- \\
- \\
+ \\
+ \\
- \\
-\end{array}$ & $\begin{array}{l}+ \\
+ \\
+ \\
+ \\
+ \\
- \\
+ \\
- \\
+ \\
+ \\
+ \\
- \\
-\end{array}$ & $\begin{array}{l}- \\
+ \\
- \\
- \\
- \\
- \\
- \\
- \\
- \\
- \\
- \\
- \\
-\end{array}$ & $\begin{array}{l}+ \\
+ \\
- \\
- \\
- \\
+ \\
+ \\
+ \\
+ \\
+ \\
+ \\
- \\
-\end{array}$ \\
\hline $\begin{array}{l}\text { Thorax and abdomen } \\
\text { Congenital heart defect } \\
\text { Narrow thorax } \\
\text { Gastrointestinal anomalies } \\
\text { Renal anomalies }\end{array}$ & $\begin{array}{l}- \\
- \\
-\end{array}$ & $\begin{array}{l}- \\
- \\
-\end{array}$ & $\begin{array}{l}+ \\
- \\
- \\
-\end{array}$ & $\begin{array}{l}+ \\
+ \\
+ \\
+\end{array}$ & $\begin{array}{l}- \\
- \\
-\end{array}$ & $\begin{array}{l}- \\
- \\
-\end{array}$ \\
\hline $\begin{array}{l}\text { Musculoskeletal } \\
\text { Flexed fingers } \\
\text { Small hands and feet } \\
\text { Bilateral simian creases } \\
\text { Malposition of toes } \\
\text { Foot deformity } \\
\text { Broad first toe } \\
\text { Dysplastic hips }\end{array}$ & $\begin{array}{l}- \\
- \\
+ \\
+ \\
+ \\
+ \\
+\end{array}$ & $\begin{array}{l}+ \\
+ \\
+ \\
- \\
- \\
-\end{array}$ & $\begin{array}{l}+ \\
- \\
- \\
- \\
-\end{array}$ & $\begin{array}{l}+ \\
- \\
- \\
+ \\
+ \\
+ \\
+\end{array}$ & $\begin{array}{l}- \\
- \\
- \\
- \\
- \\
+\end{array}$ & $\begin{array}{l}+ \\
+ \\
+ \\
+ \\
+ \\
+\end{array}$ \\
\hline $\begin{array}{l}\text { Other } \\
\text { Hypospadias } \\
\text { Undescended testes }\end{array}$ & + & $\overline{+}$ & & & & \\
\hline
\end{tabular}

* Clinical features are present $(+)$, absent $(-)$, or not available (?). and ID4 and ID5 with abnormalities of the cranial sutures and heart defects. The deletions ID2, ID6, and ID7 were not associated with any distinctive malformations.

The deletion of ID4 is completely contained within ID5 and the clinical features of the two patients were similar. The patient with the ID5 deletion had all the major features of ID4, but with additional features of gastrointestinal abnormalities, renal abnormalities, and malformations of the feet. It is tempting to attribute these additional abnormalities to the extra genes which are presumably deleted at the distal overlap of ID4 and ID5.

The malformations of the two ring chromosomes will not be discussed since a deletion of the short arm of chromosome 16 is also present (unpublished data).

\section{Discussion}

A number of patients with interstitial deletions of the long arm of chromosome 16 have been reported. ${ }^{7-91319-23}$ There is obvious similarity in the pattern of malformations in different patients and this has resulted in the concept of a deletion syndrome. However, the region involved has been disputed with 16q12.2$\mathrm{q} 13^{720}$ and $16 \mathrm{q} 22^{9}$ being contenders for the critical region that, when deleted, is associated with this syndrome. There are five deletions in the region from $\mathrm{q} 12$ to $\mathrm{q} 22.1$. The deletion ID3 segregates in three members of a two generation pedigree without phenotypic effect, ${ }^{12}$ thus eliminating this region in any clinical phenotype. Deletions ID1 and ID2 are non-overlapping in the region from $\mathrm{q} 12.1$ to q13 while ID4 and ID5 are overlapping deletions in q22.1. Although there are many similarities between the clinical features of these patients there are differences. The patient with the ID1 deletion has sensorineural deafness, patients with ID4 and ID5 have abnormalities of the cranial sutures and heart defects, while the patient with the ID2 deletion did not have any distinctive malformations. The ID5 deletion was shown to extend further distally than the ID4 deletion. It could be considered that in the patient with the ID5 deletion the additional clinical abnormalities of the gastrointestinal tract, renal system, and feet could be attributed to genes deleted in this extra segment.

It is evident that analysis of the breakpoints of interstitial deletions of chromosome 16 by classical cytogenetics does not have sufficient resolution to provide meaningful correlations between the bands deleted and the phenotype. These deletions can be mapped by either molecular cytogenetic analysis using FISH, molecular characterisation of somatic cell hybrids containing the deleted chromosome, or by analysis of polymorphic microsatellite repeats. The availability of a high resolution cytogenetic based physical map of DNA markers where localisation is at an average resolution of at least $1.6 \mathrm{Mb}$ provides the basis for the sequential selection of DNA markers for rapid localisation of breakpoints. By mapping breakpoints using these procedures there can be 
meaningful correlations between the extent of deletions and a patient's phenotype.

The seven interstitial deletions and two ring chromosomes provide evidence that, with the exception of $16 \mathrm{q} 24.2$ to $\mathrm{q} 24.3$ for which there have been no reported cases, deletions for any region of chromosome $16 \mathrm{q}$ can be associated with a viable phenotype. It is suggested that the region q24.2 to q24.3 may be lethal when monosomic since there are no reports known to the authors of unbalanced segregants from translocations which are monosomic for this region. The one example of a deletion encompassing this region was reported when, historically, banding was of low resolution, ${ }^{6}$ and therefore this karyotype cannot be confirmed. It is hoped that further high resolution mapping of rearrangements in this region of chromosome 16 will allow further delineation of this region.

There are now several reports of patients with deletions involving Giesma dark bands who have normal phenotypes. These are 16q21 (deletion ID3 in this report), $13 \mathrm{q} 21,{ }^{24} 5 \mathrm{p} 14,{ }^{25}$ and $11 \mathrm{p} 12 .{ }^{26}$ These results support the concept that dark $\mathrm{G}$ bands are late replicating, AT rich, and with a paucity of genes. ${ }^{27}$ In contrast, the apparent lethality of deletions of the 16q24 region are consistent with the concept of a high concentration of genes in the telomeric light $G$ bands. ${ }^{28}$

We thank Sinoula Apostolou for preparing fig 2 and Norman Doggett for supplying cosmid probes on chromosome 16 . We would like to thank Dr Bernhardt and the parents of patients who have generously cooperated with this study. DFC and GRS acknowledge support from the United States Department of Energy (Grant No DE-FG02-89ER60863) and the Australian National Health and Medical Research Council.

1 Korenberg JR, Kalousek DK, Anneren G, et al. Deletion of chromosome 21 and normal intelligence: molecular defchromosome 21 and normal intelligence: molecular

2 Roberts SH, Duckett DP. Trisomy 16p in a liveborn infant and a review of partial and full trisomy 16. $\mathcal{F}$ Med Gene $1978 ; 15 \cdot 375-81$.

3 Martin RH, Balkan W, Burns K, Rademaker AW, Lin CC, Rudd NL. The chromosome constitution of 1000 human spermatozoa. Hum Genet 1983;63:305-9.

4 Taysi K, Fishman M, Sekhon GS. A terminal long arm deletion of chromosome 16 in a dysmorphic infant: 46,XY,del(16)(q22). Birth Defects 1978;14:343-7.

5 Callen DF, Baker EG, Lane SA. Re-evaluation of GM2346 from a del $(16)(\mathrm{q} 22)$ to $\mathrm{t}(4 ; 16)(\mathrm{q} 35 ; \mathrm{q} 22.1)$. Clin Genet 1990;38:466-8.

6 Fryns JP, Melchoir S, Jaeken J, van den Berghe H. Partial monosomy of the long arm of chromosome 16 in a malformed newborn: karyotype 46,XX,del(16)(q21). Hum Genet 1977;38:343-6.

7 Elder FFB, Ferguson JW, Lockhart LH. Identical twins with deletion $16 \mathrm{q}$ syndrome: evidence that $16 \mathrm{q} 12.2-\mathrm{q} 13$ is the critical band region. Hum Genet 1984;67:233-6.

8 Hoo JJ, Lowry RB, Lin CC, Haslam RHA. Recurrent de novo interstitial deletion of $16 \mathrm{q}$ in two mentally retarded sisters. Clin Genet 1985;27:420-5.

9 Fujiwara M, Yoshimoto T, Morita Y, Kamada M. Interstitial deletion of chromosome $16 \mathrm{q}: 16 \mathrm{q} 22$ is critical for $16 \mathrm{q}-$ syndrome. Am 7 Med Genet 1992;43:561-4.

10 Schuffenhauer S, Callen DF, Seidel H, Shen Y, Lederer G, Murken J. De novo interstitial deletion 16(q12.1q13) of paternal origin in a 10-year-old boy. Clin Genet 1992;42:246-50.

11 Van Thienen MN, Van Roy BC, Willems PJ, et al. A new patient with deletion $16 \mathrm{q}(12.2-21)$. In preparation.

12 Witt DR, Lew SP, Mann J. Heritable deletion of band $16 \mathrm{q} 21$ with normal phenotype: relationship to late replicating DNA. Am f Hum Genet 1988;43:A127.

13 Cooke A, Tolmie J, Darlington W, Boyd E, Thomson R, Ferguson-Smith MA. Confirmation of a suspected $16 \mathrm{q}$ deletion in a dysmorphic child by flow karyotype analysis. f Med Genet 1987;24:88-92.

14 McDonald DM, Spinner NB, King MC, Emanuel BS, Zackai EH. Interstitial deletion of $16 \mathrm{q}$ in two patients: confirmation of cytogenetics by analysis of haptoglobin levels. Am F Hum Genet 1987;41:A132.

15 Quintana A, Sordo MT, Estevez C, Ludena MC, San Roman C. 16 ring chromosome. Clin Genet 1983;23:243. 16 Neidengard L, Sparkes RS. Ring chromosome 16. Hum Genet 1981;59:175-7.

17 Callen DF, Doggett NA, Stallings RL, et al. High-resolution cytogenetic-based physical map of human chromosome 16. Genomics 1992;13:1178-85.

18 Callen DF, Baker E, Eyre HJ, Chernos JE, Bell JA, Sutherland GR. Reassessment of two apparent deletions of chromosome $16 \mathrm{p}$ to an ins $(11 ; 16)$ and a $t(1 ; 16)$ by chromosome painting. Ann Genet (Paris) 1990;33.219 21.

19 Lin CC, Lowry RB, Snyder FF. Interstitial deletion for a region in the long arm of chromosome 16. Hum Genet 1983;65:134-8.

20 Naritomi K, Shiroma N, Izumikawa Y, Sameshima K, Ohdo S, Hirayama K. 16q21 is critical for $16 \mathrm{q}$ deletion syndrome. Clin Genet 1988;33:372-5.

21 Natt E, Magenis RE, Zimmer J, Mansouri A, Scherer G. Regional assignment of the human loci for uvomorulin (UVO) and chymotrypsinogen B (CTRB) with the help of two overlapping deletions on the long arm of chromosome 16. Cytogenet Cell Genet 1989;50:145-8.

22 Casamassima AC, Klein RM, Wilmot PL, Brenholz P, Shapiro LR. Deletion of $16 \mathrm{q}$ with prolonged survival and unusual radiographic manifestations. Am $f$ Med Genet unusual radiog

23 Edelhoff S, Maier B, Trautmann U, Pfeiffer RA. Interstitial deletion of 16(q13q22) in a newborn resulting from a paternal insertional translocation. Ann Genet (Paris) 1991;34:85-9.

24 Couturier J, Morichon-Delvallez N, Dutrillaux B. Deletion of band $13 \mathrm{q} 21$ is compatible with normal phenotype. Hum Genet 1985;70:87-91.

25 Overhauser J, Golbus MS, Schonberg SA, Wasmuth JJ. Molecular analysis on an unbalanced deletion of the short arm of chromosome 5 that produces no phenotype. $A m f$ Hum Genet 1986;39:1-10.

26 Barber JCK, Mahl H, Portch J, Crawford MdA. Interstitial deletions without phenotypic effect: prenatal diagnosis of a new family and brief review. Prenat Diagn 1991;11:41116.

27 Manuelidis L. A view of interphase chromosomes. Science 1990;250:1533-40.

28 Saccone S, De Sario A, Valle GD, Bernardi G. The highest gene concentrations in the human genome are in telomeric bands of metaphase chromosomes. Proc Natl Acad Sci USA 1992;89:4913-17. 